\title{
Genetic Variability and Character Association Studies in Indigenous Ahu Rice Germplasm of Assam, India
}

\author{
Jyotirupa Kalita, Priyanka Bairagi, Gargi Kashyap, M.K. Sarma*, \\ Sangeeta Baruah and Anwesha A. Sharma
}

BN College of Agriculture, Biswanath Chariali, Biswanath, Assam- 784 176, India

*Corresponding author

\begin{abstract}
Keywords
Genetic variation, Correlation, Path analysis, Rainfed upland Rice

Article Info

Accepted:

20 May 2018

Available Online:

10 June 2018 yield. Heritability in broad sense was highest for grain weight followed by days to flowering and plant height. High magnitude of heritability, however, was observed for all the traits under study. Panicle weight exhibited highest genetic advance as per cent of mean followed by number of primary branches per plant and number of secondary branches per plant. The scope for further improvement of these traits through selection, thus, was indicated. Correlation studies revealed that grain yield was positively and significantly associated with effective tillers per plant, panicle length, and 100-grain weight. Path analysis also revealed considerable direct effect of these traits. Nonsignificant association of important yield attributes, viz., number of primary and secondary branches per panicle, panicle weight and filled grains per panicle with grain yield indicated the need of detail analysis of their direct and indirect effects on grain yield. This is due to their negative significant association with effective tillers per plant having the highest positive correlation with grain yield. However, based on their indirect effects via other yield components, the importance of them could be realized. Therefore, breaking these negative associations through appropriate crossing programme may be suggested for further genetic improvement in this group of rice germplasm.
\end{abstract}

\section{A B S T R A C T}

Genetic variability and character association for grain yield and its component traits were studied in a set of 90 rice genotypes under rainfed direct seeded condition of Assam. Highest genotypic coefficient of variation was observed for panicle weight, followed by number of primary branches per plant, number of secondary branches per plant and grain

\section{Introduction}

Rice is the principal cereal crop in the South East Asian countries including India. It is the only crop providing staple food to the people of North East India. Rice is grown throughout the year in the state of Assam in a wide range of ecosystems ranging from deep water to the upland hill region. However, the productivity of the rainfed direct seeded rice is only 1.2 t/ha (Bhattacharyya et al., 2015). Very less scientific attention was paid in the past for improvement of this group of rice in the region in comparison to the other groups. Moreover, in view of large water demand of transplanted rice, it has become necessary to give impetus in improving the productivity of upland direct seeded rice. The state of Assam 
and adjoining parts of North East India is the traditional home for a large array of rice germplasm. Altogether, 13 categories of rices are known to exist in the state (Sarma et al., 2015). Out of them the Ahu group represents the genotypes characterized by early maturity, photo insensitivity, tolerance to moisture stress of various degrees and adaptation under upland environment. A total of 1003 upland adapted rice germplasm are known to exist and are being conserved in the state of Assam (Das and Ahmed, 1995). However, in view of their low yield potentiality it is necessary to undertake breeding programme for genetic improvement of them. In order to exploit the variability in this group of rice germplasm and to understand the character association pattern as an aid in selection programme this investigation was carried out in a set of 90 upland rice genotypes collected from the All India Coordinated Research Project, Dryland Agriculture, B. N. College of Agriculture, Assam, India.

\section{Materials and Methods}

The experiment was carried out during Kharif season of 2017 with 90 upland rice genotypes under rainfed upland direct seeded situation in the experimental field of Biswanath College of Agriculture, AAU, Biswanath Chariali, Assam. The experiment was laid out in a randomized block design with three replications. Each plot consisted of three rows of three meter length. Seeds were direct sown in line with $20 \mathrm{~cm}$ inter row spacing maintaining $5 \mathrm{~cm}$ seedling to seedling distance for assessment of individual plant performance and the crop was raised following the recommended package of practices under rainfed upland condition of Assam. Ten plants were randomly selected from each plot to record the yield attributes viz. Plant height, Effective tillers per plant, Panicle length, Number of primary branches per plant, Number of secondary branches per plant, Panicle weight and Filled Spikelets per panicle. Grain weight was taken for 100 random filled grains. The days to $50 \%$ flowering and maturity was recorded on plot basis. Seed yield was recorded on randomly taken one meter length of crop row. The data were subjected to the analysis of variance of RBD design with three replications following Panse and Sukhatme (1967). The mean sum of squares obtained from the analysis of variance were subjected to estimation of genetic parameters of variation as per Singh \& Choudhury (1988). Estimates of variability parameters, heritability and genetic advance were calculated using standard methods of Burton and Devane (1953) and Johnson et al., (1955). The mean of three replications was used for statistical analysis to compute correlation coefficients, and path coefficient analysis with direct and indirect effect on yield following Wright (1921).

\section{Results and Discussion}

Significant mean sum of squares for all the 11 quantitative traits under study indicated existence of wide range of variability in the set of rice genotypes under study. The estimates of various genetic parameters of variation are presented in Table 1. Highest Genotypic and phenotypic variance was observed for number of filled spikelet per panicle followed by days to maturity and plant height. Good agreement between the phenotypic observations with the genotypic values was observed for all the traits under study. Similar observations were also made by Manikya and Reddy (2011) and Sarma et al (2015). Studying the magnitude of variance does not merely justify the comparison of variability exhibited by different traits. Coefficient of variation takes into account the mean of each character which gives the real basis for comparison of variability. In the present investigation, highest coefficient of variation due to genotype was exhibited by panicle weight, 
followed by number of primary branches per plant, number of secondary branches per plant and grain yield. There was good agreement between the genotypic coefficient of variation and phenotypic coefficient of variation indicating less influence of environmental variance for all the traits under study. Presence of high magnitude of variation is also not the sole criterion for effectiveness of selection (Burton, 1952). Therefore, estimation of heritability and genetic advance are also required to arrive at more reliable conclusion (Sarma and Richharia, 1995). In the present study, heritability in broad sense was observed highest for grain weight followed by days to flowering and plant height. Considerably high (> $80 \%$ ) heritability in broad sense was, however, observed for all other traits under study. Genetic advance as per cent of mean was observed highest for panicle weight followed by number of primary branches per plant and by number of secondary branches per plant. High heritability coupled with high genetic advance indicates effectiveness of selection (Johnson et al., 1959, and Gandhi et al., 1964). Based on the above observation it may be concluded that selection for the traits, viz., panicle weight, primary branches per panicle and secondary branches per panicle should be considered for further improvement in the set of germplasm under study.

While estimates of variability parameters indicate the effectiveness of selection for a trait of concern, character association studies provide information on the set of traits to be considered for selection for improvement in yield. Simple correlation studies along with path analysis can give us a picture of direct and indirect influence of different component traits on grain yield which provide us the basis of selection. The phenotypic correlation matrix amongst 11 traits under study is presented in Table 2. Highest significant positive correlation of grain yield was observed with effective tillers per plant followed by 100-grain weight and panicle length. Path analysis also revealed considerable direct effect of these traits. On the other hand, no significant negative association of component traits was observed with grain yield. However, negative significant association of important yield attributes, viz., number of primary and secondary branches per panicle, filled spikelets per panicle and panicle weight with effective tillers per plant having the highest positive correlation with grain yield appeared to be of concern in this group of rice genotypes. Breaking this negative correlation is, therefore, desirable which may be achieved following recombination breeding approach.

Panicle weight was negatively associated with effective tillers per plant and filled spikelets per panicle. However, it's significant association with number of primary and secondary branches per panicle further indicated the scope recombination breeding to accumulate all the desirable component traits contributing to grain yield. Based on the above, it may be concluded that direct selection for the traits effective tillers per plant, 100 grain weight and panicle length may be advocated to obtain improvement in grain yield.

Yield is a complex trait which is influenced by many component traits. Therefore, apart from the direct effect an independent trait may have some influence via other component traits. The direct and indirect effect of all the traits can be dissected out by path analysis. The results of phenotypic path coefficient of yield and yield contributing characters discussed here are presented in Table 3. Highest positive direct effect was observed for filled spikelets per panicle followed by effective tillers per plant, the former having no significant correlation with yield and the later having the highest significant positive association with grain yield. 
Table.1 Genetic parameters of variation for 11 quantitative traits in rice under rainfed upland situation

\begin{tabular}{|c|c|c|c|c|c|c|c|c|c|c|c|}
\hline $\begin{array}{l}\text { Genetic } \\
\text { parameters }\end{array}$ & $\begin{array}{l}\text { Days to } \\
50 \% \\
\text { flowering }\end{array}$ & $\begin{array}{l}\text { Days to } \\
\text { maturity }\end{array}$ & $\begin{array}{l}\text { Plant } \\
\text { Height } \\
\text { (cm) }\end{array}$ & $\begin{array}{l}\text { Effective } \\
\text { tillers } \\
\text { per } \\
\text { plant }\end{array}$ & $\begin{array}{l}\text { Panicle } \\
\text { length } \\
\text { (cm) }\end{array}$ & $\begin{array}{l}\text { Number of } \\
\text { primary } \\
\text { branches } \\
\text { per plant }\end{array}$ & $\begin{array}{l}\text { Number } \\
\text { of } \\
\text { secondary } \\
\text { branches } \\
\text { per plant }\end{array}$ & $\begin{array}{l}\text { Panicle } \\
\text { weight }\end{array}$ & $\begin{array}{l}\text { Filled } \\
\text { spikelets } \\
\text { per } \\
\text { panicle }\end{array}$ & $\begin{array}{l}\text { 100- } \\
\text { grain } \\
\text { weight } \\
\text { (g) }\end{array}$ & $\begin{array}{l}\text { Grain yield } \\
\text { per meter } \\
\text { row length }\end{array}$ \\
\hline $\begin{array}{l}\text { Range: } \\
\text { Max }\end{array}$ & 119 & 160 & 148.6 & 12.0 & 28.2 & 15.4 & 38.6 & 4.87 & 227.7 & 3.55 & 133.01 \\
\hline $\begin{array}{l}\text { Range: } \\
\text { Min }\end{array}$ & 66 & 98 & 66.9 & 4.0 & 15.6 & 5.4 & 6.9 & 1.03 & 53 & 1.27 & 24.71 \\
\hline Mean & 99.54 & 133.28 & 111.89 & 6.35 & 20.50 & 8.5 & 22.3 & 2.48 & 97.98 & 1.85 & 54.67 \\
\hline $\begin{array}{l}\text { Phenotypic } \\
\text { variance }\end{array}$ & 356.54 & 454.76 & 356.20 & 1.56 & 5.64 & 15.3 & 65.5 & 8.8 & 529.32 & 0.210 & 355.50 \\
\hline $\begin{array}{l}\text { Genotypic } \\
\text { variance }\end{array}$ & 351.78 & 444.45 & 350.23 & 1.41 & 5.32 & 14.8 & 58.5 & 8.1 & 499.25 & 0.199 & 306.76 \\
\hline PCV & 18.97 & 16.00 & 16.87 & 19.67 & 11.58 & 46.02 & 36.29 & 119.62 & 23.48 & 24.77 & 34.49 \\
\hline GCV & 18.84 & 15.82 & 16.73 & 18.70 & 11.25 & 45.26 & 34.30 & 114.76 & 22.80 & 24.11 & 32.04 \\
\hline $\begin{array}{l}\text { Heritability } \\
\text { (bs) } \%\end{array}$ & 98.66 & 97.73 & 98.32 & 90.38 & 94.33 & 96.73 & 89.31 & 92.05 & 94.32 & 94.76 & 86.29 \\
\hline $\begin{array}{l}\text { Genetic } \\
\text { advance }\end{array}$ & 38.38 & 42.93 & 38.23 & 2.33 & 4.61 & 7.79 & 14.89 & 5.62 & 44.70 & 0.89 & 33.52 \\
\hline $\begin{array}{l}\text { Genetic } \\
\text { advance } \\
\text { ( } \% \text { of } \\
\text { mean) }\end{array}$ & 38.56 & 32.21 & 34.17 & 36.62 & 22.51 & 91.70 & 66.77 & 226.81 & 45.62 & 48.35 & 61.31 \\
\hline CV & 2.19 & 2.41 & 2.18 & 6.10 & 2.76 & 8.32 & 11.86 & 33.74 & 5.60 & 5.67 & 12.77 \\
\hline
\end{tabular}


Table.2 Correlation coefficients among 11 quantitative traits in rice under rainfed upland situation

\begin{tabular}{|c|c|c|c|c|c|c|c|c|c|c|}
\hline Variables & $\begin{array}{l}\text { Days to } \\
\text { maturity }\end{array}$ & $\begin{array}{l}\text { Plant } \\
\text { Height } \\
\text { (cm) }\end{array}$ & $\begin{array}{l}\text { Effective } \\
\text { tillers } \\
\text { per } \\
\text { plant }\end{array}$ & $\begin{array}{l}\text { Panicle } \\
\text { length } \\
\text { (cm) }\end{array}$ & $\begin{array}{l}\text { Number } \\
\text { of } \\
\text { primary } \\
\text { branches } \\
\text { per } \\
\text { plant }\end{array}$ & $\begin{array}{l}\text { Number } \\
\text { of } \\
\text { secondary } \\
\text { branches } \\
\text { per plant }\end{array}$ & $\begin{array}{l}\text { Panicle } \\
\text { weight }\end{array}$ & $\begin{array}{l}\text { Filled } \\
\text { spikelets } \\
\text { per } \\
\text { panicle }\end{array}$ & $\begin{array}{l}100- \\
\text { grain } \\
\text { weight } \\
\text { (g) }\end{array}$ & $\begin{array}{l}\text { Grain } \\
\text { yield per } \\
\text { meter } \\
\text { row } \\
\text { length }\end{array}$ \\
\hline $\begin{array}{l}\text { Days to } 50 \% \\
\text { flowering }\end{array}$ & $0.64^{* *}$ & 0.14 & -0.19 & 0.07 & -0.01 & 0.10 & 0.19 & -0.02 & 0.03 & 0.19 \\
\hline $\begin{array}{l}\text { Days to } \\
\text { maturity }\end{array}$ & & 0.07 & -0.16 & 0.01 & 0.02 & 0.14 & 0.11 & 0.03 & 0.00 & -0.05 \\
\hline $\begin{array}{l}\text { Plant Height } \\
\text { (cm) }\end{array}$ & & & -0.21 & $0.47^{* *}$ & $0.34^{* *}$ & $0.34^{* *}$ & $0.57^{* *}$ & $0.30+* *$ & $0.37^{* *}$ & 0.16 \\
\hline $\begin{array}{l}\text { Effective tillers } \\
\text { per plant }\end{array}$ & & & & -0.20 & $-0.42^{* *}$ & $-0.25^{* *}$ & $-0.34^{* *}$ & $-0.35^{* *}$ & $0.24^{*}$ & $0.46^{* *}$ \\
\hline $\begin{array}{l}\text { Panicle length } \\
\text { (cm) }\end{array}$ & & & & & $0.62^{* *}$ & $0.42^{* *}$ & $0.53^{* *}$ & $0.47^{* *}$ & 0.17 & $0.25^{* *}$ \\
\hline $\begin{array}{l}\text { Number of } \\
\text { primary } \\
\text { branches per } \\
\text { plant }\end{array}$ & & & & & & $0.58^{* *}$ & $0.60^{* *}$ & $0.69^{* *}$ & -0.05 & 0.09 \\
\hline $\begin{array}{l}\text { Number of } \\
\text { secondary } \\
\text { branches per } \\
\text { plant }\end{array}$ & & & & & & & $0.54^{*}$ & $0.91^{* *}$ & $-0.38^{* *}$ & 0.02 \\
\hline Panicle weight & & & & & & & & $-0.34 * *$ & $0.26^{*}$ & 0.11 \\
\hline $\begin{array}{l}\text { Filled spikelets } \\
\text { per panicle }\end{array}$ & & & & & & & & & $-0.29^{* *}$ & 0.08 \\
\hline $\begin{array}{l}\text { 100-grain } \\
\text { weight }(\mathrm{g})\end{array}$ & & & & & & & & & & $0.32^{* *}$ \\
\hline
\end{tabular}


Table.3 Direct and indirect effect of 11 quantitative traits in rice under rainfed upland situation

\begin{tabular}{|c|c|c|c|c|c|c|c|c|c|c|}
\hline $\begin{array}{l}\text { Genetic } \\
\text { parameters }\end{array}$ & $\begin{array}{l}\text { Days to } \\
\text { maturity }\end{array}$ & $\begin{array}{l}\text { Plant } \\
\text { Height } \\
(\mathrm{cm})\end{array}$ & $\begin{array}{l}\text { Effective } \\
\text { tillers } \\
\text { per } \\
\text { plant }\end{array}$ & $\begin{array}{l}\text { Panicle } \\
\text { length } \\
(\mathrm{cm})\end{array}$ & $\begin{array}{l}\text { Number } \\
\text { of } \\
\text { primary } \\
\text { branches } \\
\text { per plant }\end{array}$ & $\begin{array}{l}\text { Number } \\
\text { of } \\
\text { secondary } \\
\text { branches } \\
\text { per plant }\end{array}$ & $\begin{array}{l}\text { Panicle } \\
\text { weight }\end{array}$ & $\begin{array}{l}\text { Filled } \\
\text { spikelets } \\
\text { per } \\
\text { panicle }\end{array}$ & $\begin{array}{l}\text { 100- } \\
\text { grain } \\
\text { weight } \\
\text { (g) }\end{array}$ & $\begin{array}{l}\text { Correlation } \\
\text { with grain } \\
\text { yield }\end{array}$ \\
\hline $\begin{array}{l}\text { Days to } \\
\text { maturity }\end{array}$ & 0.091 & 0.004 & -0.086 & 0.006 & -0.032 & -0.051 & -0.014 & 0.024 & -0.002 & -0.05 \\
\hline $\begin{array}{l}\text { Plant } \\
\text { Height }(\mathrm{cm})\end{array}$ & 0.006 & 0.057 & -0.114 & 0.101 & -0.008 & -0.114 & -0.068 & 0.171 & 0.093 & 0.13 \\
\hline $\begin{array}{l}\text { Effective } \\
\text { tillers per } \\
\text { plant }\end{array}$ & -0.014 & -0.012 & 0.539 & -0.043 & 0.045 & 0.084 & 0.041 & -0.197 & 0.060 & $0.46 * *$ \\
\hline $\begin{array}{l}\text { Panicle } \\
\text { length }(\mathrm{cm})\end{array}$ & 0.003 & 0.027 & -0.108 & 0.213 & -0.101 & -0.139 & -0.062 & 0.262 & 0.028 & $0.25^{* *}$ \\
\hline $\begin{array}{l}\text { Number of } \\
\text { primary } \\
\text { branches } \\
\text { per plant }\end{array}$ & 0.009 & 0.016 & -0.113 & 0.065 & -0.231 & -0.092 & -0.045 & 0.342 & -0.123 & 0.09 \\
\hline $\begin{array}{l}\text { Number of } \\
\text { secondary } \\
\text { branches } \\
\text { per plant }\end{array}$ & 0.014 & 0.019 & -0.135 & 0.088 & 0.165 & -0.337 & -0.064 & 0.457 & -0.070 & -0.02 \\
\hline $\begin{array}{l}\text { Panicle } \\
\text { weight }\end{array}$ & 0.011 & 0.032 & -0.184 & 0.112 & -0.165 & -0.181 & -0.119 & 0.370 & 0.067 & 0.11 \\
\hline $\begin{array}{l}\text { Filled } \\
\text { spikelets } \\
\text { per panicle } \\
\end{array}$ & 0.004 & 0.017 & -0.189 & 0.099 & -0.198 & -0.274 & -0.078 & 0.563 & -0.074 & 0.08 \\
\hline $\begin{array}{l}\text { 100-grain } \\
\text { weight }(\mathrm{g})\end{array}$ & -0.001 & 0.021 & 0.128 & 0.024 & 0.056 & 0.093 & -0.031 & 0.165 & 0.254 & $0.23^{* *}$ \\
\hline
\end{tabular}

$\mathrm{R}=0.34$ 
Colinearity of these findings could also be obtained from the works done by Sanker et al.,(2010), Basavaraja et al.,(2011), Padmaja et al.,(2011), Ravindra Babu et al.,(2012), Nagaraju et al., (2013), Rao et al., (2014) and Kalyan et al., (2017).

This might be due to negative indirect effect of filled spikelets per panicle via effective tillers per plant, primary and secondary branches per panicle. Effective tillers per plant had very less indirect effect via all other traits. The former Direct effect of all other traits was observed comparatively in very lower magnitude. Negative direct effect of primary and secondary branches per plant on grain yield is however, not desirable. They, however, exhibited considerable indirect positive effect via filled spikelets per panicle. These two important yield attributes if contribute directly to yield along with the above traits, there would be further yield improvement. Panicle weight exhibited direct negative effect on grain yield. But it showed positive indirect effect via filled spikelets per panicle. Studies made by many workers viz., Mulugeta et al., (2012), Nagaraju et al., (2013) and Rao et al., (2014) for number of filled grains per panicle. Satish Chandra et al., (2009), Yadav et al., (2011), Akhtar et al., (2011), Padmaja et al., (2011) and Rahman et al., (2014) also revealed similar type of observations in various group of rice genotypes for different traits Recombination breeding to break the negative linkages is, therefore, needed. Appropriate crossing programmes may be undertaken to break the undesirable linkages and to isolate desirable recombinants in segregating generation with accumulation of favorable alleles governing the component traits.

\section{References}

Akhtar, N., Nazir, M. F., Rabnawaz, A., Mahmood, T., Safdar, M., Asif, M. E and Rehman, A. 2011. Estimation of Heritability, Correlation and Path Coefficient Analysis in Fine Grain Rice (Oryza sativa L.) J. Anim. Plant Sci. 21(4), 660-664.

Basavaraja, T., Gangaprasad, S., Dhusyantha Kumar, B. M and Shilaja Hittlamani. 2011. Correlation and path analysis of yield and yield attributes in local rice cultivars (Oryza sativa L.). Electronic $\mathbf{J}$ P1 Breed. 2(4), 523-526.

Bhattacharyya, H, Borkakoty, $\mathrm{K}$ and Ray, BK.2015. Agricultural Profile in Assam,In: Agriculture in Assam, Ed. A. Bhattacharyya, Assam Agricultural University, pp.22-50

Burton GW. 1952. Quantitative inheritance in grasses.Proc. $6^{\text {th }}$ Int.Grassland Cong. 1, 211-283

Burton GW and Devane EH. 1953. Estimating heritability in tall fescus (Festuca arrundinaceae) from replicated clonal material. Agron. J. 45, 478-481

Gandhi SM, Sanghai KS, Nathawat KS and Bhatnagar MP 1964 Genotypic variability and correlation coefficients relating to grain yield and other quantitative characters in Indian Wheat. Indian j. Genet. 24, 1-28

Johnson HW, Robinson HF and Comstock RE. 1955 Estimates of genetic and environmental variability in Soybean. Agron J. 47, 1314-1318

Kalyan, B., K.V. Radha Krishna and Subba Rao, L.V. 2017. Path Coefficient Analysis for Yield and Yield Contributing Traits in Rice (Oryza sativa L.) Genotypes. Int.J.Curr.Microbiol.App.Sci. $\quad 6(7)$, 2680-2687.

Manikya, C. M. and Reddy T. D. 2011. Studies on genetic divergence in medium duration elite rice genotypes (Orzya sativa L.). The Journal of Research ANGRAU. 39 (4), 122. 
Mulugeta Seyoum, Sentayehu Alamerew and Kassahun Bantte 2012. Genetic Variability, Heritability, Correlation Coefficient and Path Analysis for Yield and Yield Related Traits in Upland Rice (Oryza sativa L.) J Pl. Sci.. 7(1), 13-22.

Nagaraju, C., Sekhar, M.R., Reddy, K.H and Sudhakar, P. 2013. Correlation between traits and path analysis coefficient for grain yield and other components in rice (Oryza sativa L.) genotypes.Int. J. Appl. Boil. pharm. 4 (3), 137-142.

Padmaja, D., Radhika, K., Subba Rao, L.V and Padma, V. 2011. Correlation and path analysis in rice germplasm. Oryza. 48 (1), 69-72.

Panse VG and Sukhatme PV. 1967. Statistical methods for agricultural workers. ICAR Publications, New Delhi.

Rahman, M.A., Hossain, M.S., Chowdhury, I.F., Matin, M.A and Mehraj, H. 2014. Variability study of advanced fine rice with correlation, pathco-efficient analysis of yield and yield contributing characters. Int. J. Appl. Sci. Biotech. 2(3), 364-370.

Rao, V.T., Mohan, Y.C., Bhadru, D., Bharathi, D and Venkanna, V. 2014.Genetic variability and association analysis in rice. J. Appl. Boil. pharm. 5, (2).

Ravindra Babu, V., Shreya, K., Kuldeep Singh Dangi, Usharani, G., Siva Shankar, A. 2012. Correlation and Path Analysis Studies in Popular Rice Hybrids of India. Int. J. Sci. Res. Publ. 2(3), 156-158.
Sarma MK and Richaria AK 1995. Genetic variability and diversity in rice under irrigated transplanted condition. JASS. $8(2), 154-157$

Sarma, MK and Bhuyan, J. 2004. Genetic variability and divergence studies in Ahu rices of Assam. Ad. Plant Sci. 17(I), 323- 328.

Sarma, MK, Goswami, RK, Mayuri Baruah, Sarma, D and Neog, P. 2014. Genetic variability and diversity in indigenous rice germplasm of Assam under aerobic condition, Progr Agril. 15(1), 66-70

Sarma, MK, Moutuchi Bhattacharyee and Sarma, AK. 2014. Crop Genetic Resources of North East India: Current Status and Future Strategies, Prog Agril. 15(1), 28-34

Satish Chandra, B., Dayakar Reddy, T., Ansari, N. A and Sudheer Kumar, S. 2009. Correlation and path analysis for yield and yield components in rice (Oryza sativa L.) Agril Sci. Digest. 29 (1), 45-47.

Singh RK and Chaudhary BD. 1988. Biometrical Methods in Quantitative Genetic Analysis. Kalyani Publishers, New Delhi.

Wright, S. 1921. Correlation and causation. J. Agril Res. 20, 557-585.

Yadav, V.K., Yuvraj Singh, Sandeep Kumar Soni and Yadav, A. K. 2011. Genetic Divergence Analysis in Salt Tolerance Rice (Oryza sativa L.) Genotypes. Plant Archives. 11(2), 593-595.

\section{How to cite this article:}

Jyotirupa Kalita, Priyanka Bairagi, Gargi Kashyap, M.K. Sarma, Sangeeta Baruah and Anwesha A. Sharma. 2018. Genetic Variability and Character Association Studies in Indigenous Ahu Rice Germplasm of Assam, India. Int.J.Curr.Microbiol.App.Sci. 7(06): 22972304. doi: https://doi.org/10.20546/ijcmas.2018.706.275 